\title{
Pengaruh Gaya Kepemimpinan Terhadap Kinerja Karyawan Pada Depot Nanda di Kota Bekasi
}

\author{
Apri Parantoro \\ Universitas Mitra Karya \\ apriparantoro12@gmail.com
}

\begin{abstract}
The purpose of this study was to determine how much influence and the relationship between leadership style and employee performance. The data collected through a sample to represent the entire population and data collection using a questionnaire. The method used is descriptive method with data collection through questionnaires and observations. The T test results show a significant effect of leadership style on employee performance, it is proven that the variable $(X)$ leadership style and variable $(Y)$ employee performance have a significant value of 0.00 less than 0.05 , so it is concluded that the hypothesis is accepted with significantly strong.
\end{abstract}

Keywords: Leadership Style and Employee Performance

\section{Abstrak}

Tujuan dari penelitian ini adalah untuk mengetahui seberapa besar pengaruh dan hubungan antara gaya kepemimpinan dengan kinerja pegawai. Data dikumpulkan melalui sampel untuk mewakili seluruh populasi dan pengumpulan data menggunakan kuesioner. Metode yang digunakan adalah metode deskriptif dengan pengumpulan data melalui angket dan observasi. Hasil uji T menunjukkan adanya pengaruh yang signifikan gaya kepemimpinan terhadap kinerja karyawan, terbukti bahwa variabel $(X)$ gaya kepemimpinan dan variabel $(Y)$ kinerja karyawan memiliki nilai signifikansi 0,00 lebih kecil dari 0,05, sehingga disimpulkan hipotesis diterima dengan sangat kuat.

Kata Kunci: Gaya Kepemimpinan dan Kinerja Karyawan

\section{PENDAHULUAN}

Dalam era globalisasi menuntut perusahaan untuk dapat lebih bersaing. Perusahaan harus memiliki keunggulan dan daya saing. Sehingga mampu bertahan di antara perusahaan lain. Keberhasilan suatu perusahaan sangat dipengaruhi kinerja karyawannya.

Pada dasarnya semua perusahaan pasti menginginkan perkembangan yang sangat pesat, baik dibidang usaha itu sendiri, maupun lingkup usaha itu sendiri. Dengan adanya peningkatan produktifitas maka diharapkan akan mengalami peningkatan yang akan menguntungkan perusahaan. Maka dari itu perusahaan harus mempunyai kinerja yang baik bagi perusahaan, tanpa terkecuali gaya kepemimpinan juga merupakan factor utama yang mempengaruhi kualitas sumber daya yang berkopeten. Depot Nanda adalah sebuah perusahaan yang bergerak di bidang Jasa pengisian ulang air minum yang terletak di desa Harapan Jaya kecamatan Bekasi Utara Kota Bekasi. Usaha ini dilatar belakangi dari semakin meningkatnya kebutuhan masyarakat akan air minum yang berkualitas, higienis, sehat dan ekonomis. 
Depot Nanda memproduksi air minum yang diproses dari air gunung asli dan berkualitas. Bahan baku produksi air gunung di peroleh dari sumber mata air gunung langsung dan terjaga kandungan mineralnya. Menjadikan Depot Nanda adalah air minum yang sehat dan menyegarkan bagi tubuh.

Dari segi produksi, Depot Nanda memproduksi isi ulang air minum yaitu air mineral. Dan itu adalah produksi awal sebagai permulaan usaha depot pengisian ulang air minum. Dengan berjalannya waktu diharapkan dapat menambah produksi yaitu RO, hexagonal dan lain sebagainya. Pemasaran produk ini adalah masyarakat sekitar dari kalangan bawah sampai kalangan menengah. Pemasaran dengan sistem konsumen langsung datang maupun dengan delivery order. Menjadikan masyarakat lebih mudah memperoleh pelayanan dari kami.

Berdasarkan data dari depot nanda diperoleh data pada penjualan dalam 1 tahun perbandingannya dari bulan september 2019 hingga bulan september 2020 kinerja karyawan berpengaruh terhadap produktifitas perusahaan.

Penelitian ini mempunyai tujuan untuk menemukan bukti mengenai pengaruh gaya kepemimpinan terhadap kinerja karyawan, maka tujuan penelitian ini adalah :

- Untuk mengetahui apakah terdapat pengaruh gaya kepemimpinan terhadap kinerja karyawan pada Perusahaan Depot Nanda di Bekasi.

- Untuk mengetahui apakah terdapat hubungan gaya kepemimpinan terhadap kinerja karyawan pada Perusahaan Depot Nanda di Bekasi.

Hipotesis 1

Ho : Terdapat pengaruh antara variabel gaya kepemimpinan terhadap kinerja karyawan.

Ha : Terdapat pengaruh antara variabel gaya kepemimpinan terhadap kinerja karyawan.

Hipotesis 2

Ho : Terdapat hubungan antara variabel gaya kepemimpinan dengan kinerja karyawan.

Ha : Tidak terdapat hubungan antara variabel gaya kepemimpinan dengan kinerja karyawan.

Kerangka berpikir yang baik akan menjelaskan secara teoritis hubungan antara variabel yang akan diteliti. Menurut Uma Sekaran (dalam Sugiyono, 2017:60), mengemukakan bahwa kerangaka berfikir merupakan model konseptual tentang bagaimana 
teori berhubungan dengan berbagai faktor yang telah didefinisikan sebagai masalah yang penting. Sedangkan menurut Suriasumantri (dalam Sugiyono, 2017:60), kerangka pemikiran ini merupakan penjelasan sementara terhadap gejala yang menjadi objek permasalahan. Dibawah ini adalah kerangka berpikir penelitian ini mengunakan variabel gaya kepemimpinan $(\mathrm{X})$, variabel kinerja karyawan (Y). Variabel dependen akan dipengaruhi oleh variabel independen antara lain : pengaruh gaya kepemimpinan (X) yang merupakan bagian dari kegiatan sumber daya manusia yang mempunyai pengaruh terhadap variabel dependen yaitu kinerja karyawan (Y). Untuk lebih jelasnya dapat diuraikan secara singkat mengenai kerangka pemikiran tersebut.

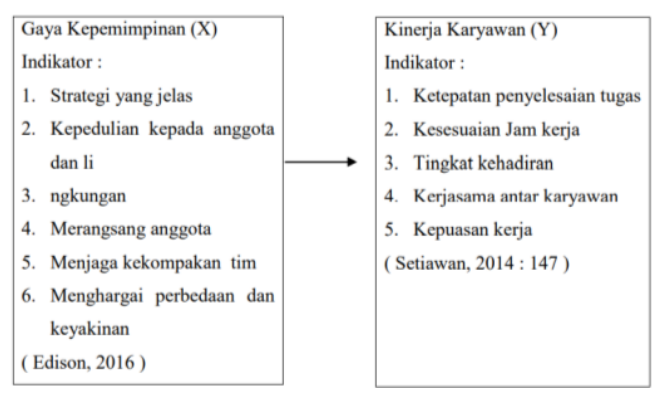

\section{Gambar 1. Kerangka Berpikir}

\section{METODOLOGI PENELITIAN}

Sejarah singkat Depot Nanda adalah sebuah usaha yang dilatar belakangi dari semakin meningkatnya kebutuhan masyarakat akan air minum yang berkualitas, higienis, sehat dan ekonomis. Pada tahun 2018 merupakan awal berdirinnya Perusahaan Depot Nanda, memproduksi air minum yang diproses dari air gunung asli dan berkualitas. Bahan baku produksi air gunung di peroleh dari sumber mata air gunung langsung dan terjaga kandungan mineralnya. Menjadikan Perusahaan Depot Nanda adalah air minum yang sehat dan menyegarkan bagi tubuh.

Dari segi produksi, Perusahaan Depot Nanda memproduksi isi ulang air minum yaitu air mineral. Dan itu adalah produksi awal sebagai permulaan usaha depot pengisian ulang air minum. Dengan berjalannya waktu diharapkan dapat menambah produksi yaitu RO, hexagonal dan lain sebagainya. Pemasaran produk ini adalah masyarakat sekitar dari kalangan bawah sampai kalangan menengah. Pemasaran dengan sistem konsumen langsung datang maupun dengan delivery order. Menjadikan masyarakat lebih mudah memperoleh pelayanan dari Perusahaan Depot Nanda.

Kuesioner ditunjukan pada karyawan di Depot Nanda. Tujuannya adalah untuk mengetahui seberapa 
besarnya hubungan gaya kepemimpinan

dalam mempengaruhi kinerja karyawan.

\section{Populasi dan Sampel}

Populasi Populasi adalah wilayah generalisasi yang terdiri atas : obyek atau subyek yang mempunyai kualitas dan karakteristik tertentu yang ditetapkan oleh peneliti untuk dipelajari dan kemudian ditarik kesimpulannya. Jadi populasi bukan hanya orang, tetapi juga obyek dan benda alam yang lain. Populasi juga bukan sekedar jumlah yang ada pada obyek atau subyek yang dipelajari, tetapi meliputi seluruh karakteristik atau sifat yang dimiliki oleh subyek atau obyek itu. Sugiyono (2017:80).

\section{Sampel}

Sampel adalah bagian dari jumlah dan karakteristik yang dimiliki oleh populasi tersebut. Bila populasi besar, dan peneliti yang tidak mungkin mempelajari semua yang ada pada populasi, misalnya karena keterbatasan dana, tenaga dan waktu, maka peneliti dapat menggunakan sampel yang diambil dari populasi itu. Apa yang dipelajari dari sampel itu, kesimpulannya akan dapat diberlakukan untuk populasi. Untuk itu sampel yang diambil dari populasi harus betul representatif (mewakili). Sugiyono (2017:81).

\section{Uji Instrumen}

Instrumen yang digunakan dalam penelitian ini menggunakan kuesioner yang dapat memberikan data yang membentuk kesiapan pada tingkat individu. Kuesioner merupakan teknik pengumpulan data yang dilakukan dengan cara memberi seperangkat pertanyaan atau pernyataan tertulis kepada responden untuk dijawabnya. Kuesioner merupakan teknik pengumpulan data yang efisien bila peneliti tahu dengan pasti variabel yang akan diukur dan tahu apa yang bisa diharapkan dari responden. Selain itu, kuesioner juga cocok digunakan bila jumlah responden secara langsung atau dikirim melalui pos atau internet. Sugiyono (2017:142). Kuesioner ditunjukan pada karyawan di Kota Depot Nanda. Tujuannya adalah untuk mengetahui seberapa besarnya pengaruh gaya kepemimpinan terhadap kinerja karyawan. 37 Kuesioner ditunjukan pada karyawan di Depot Nanda. Tujuannya adalah untuk mengetahui seberapa besarnya hubungan gaya kepemimpinan dalam mempengaruhi kinerja karyawan.

Dalam penelitian ini saya menggunakan skala likert untuk 
mengetahui hasil kuesioner. Skala likert adalah digunakan untuk mengukur sikap, pendapat, dan persepsi seseorang atau sekelompok orang tentang fenomena sosial. Dalam penelitian, fenomena sosial ini telah ditetapkan secara spesifik oleh penelitian, yang selanjutnya disebut sebagai variabel penelitian.

Dengan skala likert maka variabel yang akan diukur dijabarkan menjadi indikator variabel. Kemudian indikator tersebut dijadikan sebagai titik tolak untuk menyusun item instrumen yang dapat berupa pernyataan atau pertanyaan Sugiyono (2016:93).

Jawaban setiap item instrumen yang menggunakan skala likert mempunyai gradasi dari sangat positif sampai sangat negatif, yang dapat berupa kata antara lain:

Keterangan skor penilaian:

Sangat tidak setuju (STS) diberi skor 1

Tidak setuju (TS) diberi skor 2

Kurang Setuju (KS) diberi skor 3

Setuju (S) diberi skor 4

Sangat setuju (SS) diberi skor 5

\section{Uji Validitas}

Ghozali (2011, hal 53) mengemukakan uji validitas digunakan untuk mengukur sah atau tidaknya suatu kuesioner. Suatu kuesioner dikatakan valid jika pertanyaan pada kuesioner mampu mengungkapkan sesuatu yang akan diukur oleh kuesioner tersebut. Uji validitas dilakukan dengan membandingkan nilai $r$ hitung dengan nilai $r$ table untuk degree of feedom $d(F)=n-2$ dengan alphan 0,05. Jika $r$ itung lebih besar dari $r$ table dan $r$ positif, maka butir atau pertanyaan tersebut dikatakan valid. Untuk pengujian validitas instrument dalam penelitian ini menggunakan rumus korelasi sebagai berikut:

Rumus $\mathrm{r}_{\mathrm{X} . \mathrm{y}}=\frac{N \cdot \sum X Y-\left(\sum X\right)\left(\sum Y\right)}{\sqrt{\left\{N \sum X^{2}-\left(\sum X\right)^{2}\right\}\left\{N \sum y^{2}-\left(\sum Y\right)^{2}\right\}}}$

Keterangan:

rxy $=$ koefesien korelasi (validitas instrument).

$\mathrm{N}=$ banyaknya butir pertanyaan

$\mathrm{X}=$ Jumlah skor butir.

$\mathrm{Y}=$ Skor total responden.

$X$ 2= Jumlah kuadrat skor X.

$Y 2=$ Dalam pengujian validitas instrument menggunakan rumus korelasi product momen untuk mengetahui antara skor butir (X) dengan skor tunggal (Y) Data diolah melalui program SPSS versi 25 , untuk membuktikan hasil analisis dapat dilihat pada output uji realibilitas pada bagian corrected item total correlation. 
Jika $r$ hitung positif serta $\mathrm{r}$ hitung > $r$ table maka butir atau variabel tersebut valid.

Jika $r$ hitung tidak positif dan $r$ hitung $<\mathrm{r}$ table maka butir atau variabel tersebut tidak valid.

\section{Uji Reliabilitas}

Uji Reliabilitas adalah alat untuk mengukur suatu kuesioner yang mempunyai indikator dari variabel atau konstruk. Ghozali (2011: 47) mengemukakan sebuah kuesioner dinyatakan reliable jika jawaban seseorang terhadap pernyataan adalah konsisten atau stabil dari waktu kewaktu. Pengukuran realibilitas dapat dilakukan dengan cara: Repeated measure atau pengukuran ulang, dalam cara ini seseorang akan diberikan pertanyaan yang sama pada waktu yang berbeda, lalu kemudian dilihat apakah responden tetap konsisten dengan jawabannya. One shot atau pengukuran sekali saja. Metode pengukuran hanya dilakukan sekali saja, lalu kemudian hasilnya dibandingkan dengan pertanyaan-pertanyaan lain atau mengukur korelasi antar jawaban pertanyaan. Uji realibilitas ini dapat digunakan melalui program SPSS versi 25, yang akan memberikan fasilitas untuk mengukur nilai reliabilitas dengan menggunakan uji statistic cronbach alpa $(\alpha) .40$ Suatu konstruck atau variabel dikatakan reliable jika memberikan nilai cronbach alpa $(\alpha)>0,60$ Ghozali (2011:48). Untuk menguji reliabilitas instrument dilakukan dengan menggunakan rumus alpha cronbach dengan formula sebagai berikut:

$$
\mathrm{r}_{11}=\left(\frac{k}{k-1}\right)\left(1-\frac{\sum \alpha_{1}^{\overline{2}}}{\alpha_{1}^{2}}\right)
$$

keterangan:

r11= koefesien reliabilitas instrument.

$\mathrm{k}=$ jumlah butir yang valid.

$\sum \alpha 12=$ jumlah varians skor tiap-tiap item.

$\alpha 12=$ varians total

Uji Analisis

Dalam uji analisi terdapat uji korelasi, regresi dan determinasi berikut penjelasanya:

\section{Uji korelasi}

Secara sederhana, korelasi dapat diartikan sebagai hubungan. Namun ketika dikembangkan lebih jauh, korelasi tidak hanya dapat dipahami sebatas pengertian tersebut. Korelasi merupakan salah satu teknik analisis dalam statistik yang digunakan untuk mencari hubungan antara dua variabel yang bersifat kuantitatif. Hubungan dua variabel tersebut dapat terjadi karena adanya hubungan sebab akibat atau dapat pula terjadi karena kebetulan saja. 
Dua variabel dikatakan berkorelasi apabila perubahan pada variabel yang satu 41 akan diikuti perubahan pada variabel yang lain secara tertentu dengan arah yang sama (korelasi positif) atau berlawanan (korelasi negatif). Cara termudah untuk melihat apakah dua variabel berhubungan adalah dengan melihat apakah mereka memiliki covarian. Pemahaman atas corvarian menurut kita memahami konsep varian. Varian suatu variabel mewakili nilai rata perbedan data variabel tersebut dengan nilai mean-nya. Adapun rumus pearson produk momen (r) adalah sebagai berikut:

$$
r_{x y}=\frac{n \sum x_{i} y_{i}-\left(\sum x_{i}\right)\left(\sum y_{i}\right)}{\sqrt{\left\{n \sum x_{i}^{2}-\left(\sum x_{i}\right)^{2}\right\}-\left\{n \sum y_{i}^{2}-\left(\sum y_{i}\right)^{2}\right\}}}
$$

\section{Keterangan:}

$r x y=$ koefesien korelasi pearson

$x i=$ variabel independent

$y i=$ variabel dependen

$n$ = banyak sampel

Dari hasil yang diperoleh dari rumus di atas, dapat diketahui tingkat pengaruh variabel x dan variabel y. pada hakikatnya nilai $r$ dapat bervariasi dari 1 hingga +1 , atau secara matematis dapat ditulis menjadi $-1<\mathrm{r}<+1$. Hasil dari perhitungan akan memberikan tiga alternatif, yaitu: Bila $r=0$ atau mendekati 0 , maka korelasi antara kedua variabel sangat lemah atau tidak terdapat hubungan antara variabel $\mathrm{x}$ terhadap variabel y. Bila $r=+1$ atau mendekati +1 , maka korelasi antara kedua variabel adalah kuat dan searah, diakatakan positif. Bila $\mathrm{r}=-1$ atau mendekati -1 , maka korelasi antara kedua variabel adalah kuat dan berlawanan arah, dikatakan negative.

\section{Uji Determinasi}

Koefisien determinasi bertujuan untuk mengukur seberapa jauh kemampuan perhitungan dalam menerangkan variasi variabel terikat (dependen). Nilai koefisien determinasi adalah diantara nol dan satu. Pada pengujian hipotesis, hipotesis pertama koefisien determinasi dilihat dari besarnya nilai $\left(\mathrm{R}^{2}\right)$ untuk mengetahui seberapa jauh variabel bebas yaitu penetapan harga serta pengaruhnya terhadap minat beli. Nilai $\left(\mathrm{R}^{2}\right)$ mempunyai interval antara 0 dan 1 . Jika nilai $\mathrm{R}^{2}$ bernilai besar (mendeteksi 1) berarti variabel bebas dapat memberikan hampir semua informasi yang dibutuhkan untuk memprediksi variabel dependen. Sedangkan jika $\left(R^{2}\right)$ bernilai kecil berarti kemampuan variabel bebas dalam menjelaskan variabel dependen sangat terbatas. Secara umum koefisien determinasi untuk data silang 
(crossection) relatif rendah karena adanya variasi yang besar antara masing pengamatan, sedangkan untuk data runtun waktu (time series) biasanya mempunyai nilai koefisien determinasi yang tinggi (Ghozali 2011:97). Nilai koefisien determinasi yang kecil berarti kemampuan variabel independen dalam menjelaskan variasi variabel dependen itu terbatas. Nilai yang mendekati satu berarti variabel independen memberikan hampir semua informasi yang dibutuhkan untuk menjelaskan /memprediksi variasi variabel dependen.

\section{Uji Regresi}

Regresi dipergunakan untuk mengelolah hubungan antara dua variabel atau lebih, terutama untuk menelusuri pola hubungan yang modelnya belum diketahui dengan sempurna, atau untuk mengetahui bagaimana variabel independen berpengaruh terhadap variabel dependen dalam suatu fenomena yang kompleks. Persamaan regresi digunakan untuk menguji signifikasi pengaruh variabel bebas (Kepemimpinan) terhadap variabel terikat (Kinerja). Secara umum persamaan regresi dapat dirumuskan sebagai berikut:

$$
\mathrm{Y}=\mathrm{a}+\mathrm{bX}
$$

Keterangan:

$\mathrm{Y}=$ Nilai yang diprediksikan

$\mathrm{a}=$ Konstanta

$\mathrm{b}=$ Koefisien regresi

$\mathrm{X}=$ Nilai variabel independen.

\section{Uji Hipotesis}

Hipotesis merupakan dugaan, kesimpulan atau jawaban sementara terhadap permasalahan yang telah di rumuskan di dalam rumusan masalah sebelumnya (Marpaung, 2021).

\section{Uji Statistik t}

Uji ini bertujuan untuk menguji pengaruh secara parsial antara variabel bebas terhadap variabel terikat dengan mengasumsikan variabel lain adalah konstan. Hasil pengujian terhadap tstatistik adalah: 1. Jika sig $\mathrm{t}$ table dan koefisien $\beta$ positif, maka hipotesis diterima. 2. Jika sig t table dan koefisien $\beta$ negatif, maka hipotesis ditolak. Uji t digunakan untuk menguji apakah variabel independen secara parsial mempunyai pengaruh yang signifikan terhadap variabel dependen. Variabel independen dikatakan secara parsial berpengaruh signifikan terhadap variabel dependen apabila signifikan $($ sig $)<\alpha$ yaitu 0.05 . adapun tanda positif (+) atau negatif (-) dari Beta dan t menunjukkan arah variabel. Apabila negatif (-) maka variabel tersebut 
berpengaruh negatif artinya menurunkan tingkat volume penjualan dan apabila positif (+) maka variabel independen berpengaruh positif yang berarti meningkatkan volume penjualan.

\section{HASIL DAN PEMBAHASAN}

\section{Analisa dan penyajian data deskriptif}

Untuk mendapatkan gambaran mengenai karakteristik karyawan yang terpilih sebagai responden, berikut ini diuraikan pengelompokkan berdasarkan jenis jenis kelamin responden, pendidikan responden dan usia responden.

\section{Responden Berdasarkan Jenis Kelamin}

Adapun data mengenai jenis kelamin responden yang ditemukan pada Perusahaan Depot Nanda di Bekasi adalah sebagai berikut :

Tabel 1. Profil responden berdasarkan jenis kelamin

\begin{tabular}{|l|l|l|}
\hline $\begin{array}{l}\text { Jenis } \\
\text { Kelamin }\end{array}$ & Jumlah & Persentase \\
\hline Laki-laki & 19 & $54 \%$ \\
\hline Perempuan & 16 & $46 \%$ \\
\hline Total & 35 & $100 \%$ \\
\hline
\end{tabular}

Berdasarkan keterangan pada tabel

1. dapat diketahui bahwa dari 35 responden, jumlah responden yang berjenis kelamin laki-laki sebanyak 19 orang dengan persentase 54\%, sedangkan yang berjenis kelamin perempuan sebanyak 16 orang dengan persentase 46\%. Dari hasil kuesioner berdasarkan jenis kelamin karyawan lebih banyak laki-laki.

\section{Responden berdasarkan Pendidikan}

Adapun data mengenai pendidikan responden yang ditemui pada Perusahaan Depot Nanda di Bekasi adalah sebagai berikut:

Karakteristik responden berdasarkan pendidikan

Pendidikan Jumlah Persentasi Sma / Smk $\quad 19 \quad 54 \%$

D3 $2 \quad 6 \%$

S1 $\quad 12 \quad 34 \%$

S2 $2 \quad 6 \%$

S3

Total $\quad 35 \quad 100 \%$

Berdasarkan keterangan pada data di atas diketahui bahwa dari 35 responden, jumlah responden pada tingkat SMA/SMK sebanyak 19 orang dengan persentase 54\%, tingkat pendidikan D3 sebanyak 2 orang dengan persentase $6 \%$, tingkat pendidikan S1 sebanyak 12 orang dengan persentase $34 \%$, tingkat pendidikan S2 sebanyak 2 orang dengan persentase $6 \%$, dan tingkat pendidikan S3 sebanyak 0 orang. Dari hasil kuesioner berdasarkan jenis 
pendidikan karyawan lebih banyak Sma atau Smk.

\section{Karakteristik}

\section{Responden}

\section{Berdasarkan Usia}

Adapun data mengenai usia responden yang ditemukan pada Perusahaan Depot Nanda di Bekasi adalah sebagai berikut :

Tabel 2. Karakteristik berdasarkan usia responden

\begin{tabular}{|l|l|l|}
\hline Usia & Jumlah & Persentasi \\
\hline $17-23$ & 15 & $43 \%$ \\
\hline $23-30$ & 8 & $23 \%$ \\
\hline 30 ke atas & 12 & $34 \%$ \\
\hline Total & 35 & $100 \%$ \\
\hline
\end{tabular}

Berdasarkan keterangan pada tabel

2. Di atas diketahui bahwa dari 35 responden, jumlah responden pada usia 17-23 tahun sebanyak 15 orang dengan persentase $43 \%$, usia $24-30$ tahun sebanyak 8 orang dengan persentase $23 \%$, usia 30 tahun ke atas sebanyak 12 orang dengan persentase 34\%. Dari hasil kuesioner berdasarkan usia karyawan lebih banyak kaum remaja.

\section{Analisis Statistik Deskriptif}

Uji analisis deskriptif digunakan untuk mengetahui gambaran mengenai variabel yang diteliti melalui rata-rata (mean), nilai maksimum, nilai minimum. Standar deviasi, range dan varian.

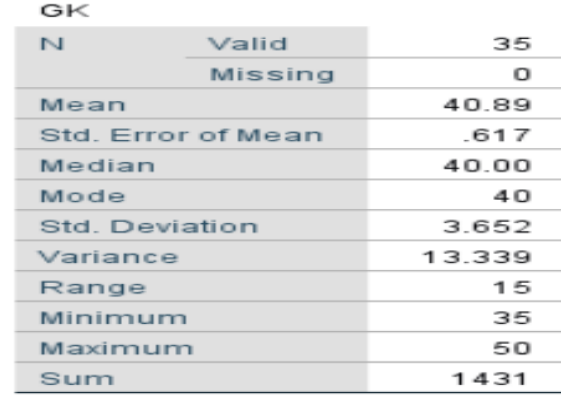

\section{Gambar 2. Hasil uji statistik deskriptif variable gaya kepemimpinan $(\mathbf{X})$}

Berdasarkan gambar variabel kepemimpinan $(\mathrm{X})$ dengan responden berjumlah 35 orang yang menjawab angket pernyataan, memiliki nilai ratarata (means) sebesar 40,89 nilai tengah (median) sebesar 40,00 niai yang sering muncul (modus) sebesar 40 (standar deviation) sebesar 3,652 (variance) sebesar 13,339 (range) sebesar 15 N.Minimum sebesar 35 dan N.Maksimum sebesar 50.

\begin{tabular}{|c|c|c|}
\hline \multirow[t]{2}{*}{$N$} & Valid & 35 \\
\hline & Missing & 0 \\
\hline \multicolumn{2}{|c|}{ Mean } & 40.34 \\
\hline \multicolumn{2}{|c|}{ Std. Error of Mean } & .741 \\
\hline \multicolumn{2}{|c|}{ Median } & 40.00 \\
\hline \multicolumn{2}{|c|}{ Mode } & 40 \\
\hline \multicolumn{2}{|c|}{ Std. Deviation } & 4.385 \\
\hline \multicolumn{2}{|c|}{ Variance } & 19.232 \\
\hline \multicolumn{2}{|c|}{ Range } & 20 \\
\hline \multicolumn{2}{|c|}{ Minimum } & 30 \\
\hline \multicolumn{2}{|c|}{ Maximum } & 50 \\
\hline \multicolumn{2}{|c|}{ Sum } & 1412 \\
\hline
\end{tabular}

Gambar 4.2 Hasil uji statistik deskriptif variable kinerja karyawan (Y)

Berdasarkan gambar variabel kinerja karyawan (y) dengan responden 
berjumlah 35 orang yang menjawab angket pernyataan, memiliki nilai ratarata (means) sebesar 40,34 nilai tengah (median) sebesar 40,00 nilai yang sering muncul (modus) sebsar 40 (standar deviation) sebesar 4,385 (variance) sebesar 19,232 (range) sebesar 20 N.Minimum sebesar 30 dan N.Maksimum sebesar 50.

\section{Hasil dan Pembahasan Uji Korelasi}

\section{Tabel 3. Korelasi}

\begin{tabular}{|c|c|c|c|}
\hline & & GK & KK \\
\hline \multirow[t]{3}{*}{ GK } & Pearson Correlation & 1 & $.706^{-2}$ \\
\hline & Sig. (2-tailed) & & .000 \\
\hline & $\mathrm{N}$ & 35 & 35 \\
\hline \multirow[t]{3}{*}{ KK } & Pearson Correlation & $.706^{-4}$ & 1 \\
\hline & Sig. (2-tailed) & .000 & \\
\hline & $\mathrm{N}$ & 35 & 35 \\
\hline
\end{tabular}
Sumber : Data Primer dikelola dengan SPSS versi 25

Berdasarkan tabel 3. diatas, terlihat koefisien korelasi sebesar $706^{* *}$. Artinya besar korelasi atau hubungan antara variabel gaya kepemimpinan terhadap kinerja karyawan sebesar 0,706 atau bisa dikatakan cukup karena mendekati angka 1. Tanda dua bintang (**) artinya korelasi signifikan hingga pada angka signifikan sebesar 0,001 .

Berdasarkan tabel diatas hubungan variabel gaya kepemimpinan terhadap kinerja karyawan signifikan karena angka signifikan sebesar 0,000 > 0,01. Arah korelasi dapat dilihat dari angka koefisien hasilnya positif atau negatif.
Sesuai dengan hasil analisis, koefisien korelasi jauh bernilai positif yaitu 0,706 maka korelasi kedua variabel bersifat searah.

\section{Hasil dan Pembahasan Uji Determinasi}

Tabel 4. Hasil Uji Determinasi

\begin{tabular}{l|l|l|l|l}
\multicolumn{9}{c}{ Model Summary } & \\
& & & Adjusted R & Std. Error of the \\
\hline Model & R & R Square & Square & \multicolumn{1}{c}{ Estimate } \\
\hline 1 & $.706^{\mathrm{a}}$ & .498 & .483 & 3.153 \\
\hline a. Predictors: (Constant), GK & & & \\
\hline
\end{tabular}

Sumber : Data primer dikelola dengan SPSS versi 25

Dilihat dari tabel 4. hasil output spss diatas didapatkan nilai $\mathrm{R}$ (koefisien determinasi) 0,498 yang artinya pengaruh gaya kepemimpinan (independen) adalah sebesar 49,8\% ini menunjukkan bahwa nilai $\mathrm{R}$ hampir mencapai angka 1 dan variabel bebas dapat memberikan hampir semua informasi yang dibutuhkan untuk memprediksi variabel terikat (dependen).

\section{Uji Reliabilitas (Konsisten)}

Reliability Statistics

Cronbach's

Alpha Based on

Cronbach's Standardized

\begin{tabular}{rrrr}
\multicolumn{1}{c|}{ Alpha } & \multicolumn{2}{|c|}{ Items } & \multicolumn{2}{c}{ N of Items } \\
\hline .751 & .863 & 11 \\
\hline .768 & .908 & 11
\end{tabular}

Gambar 3. Hasil Uji Reliabilitas Gaya Kepemimpinan dan Kinerja Karyawan 
Berdasarkan gambar variabel gaya kepemimpinan 0,756 dan variabel kinerja karyawan menunjukkan bahwa istrumen untuk setiap variabel penelitian adalah reliabel atau konsisten karena jika nilai cronbach alpha $>0,7$ maka reliabel atau konsisten.

\section{Hasil dan Pembahasan Uji Korelasi}

Tabel 5. Hasil Uji Korelasi

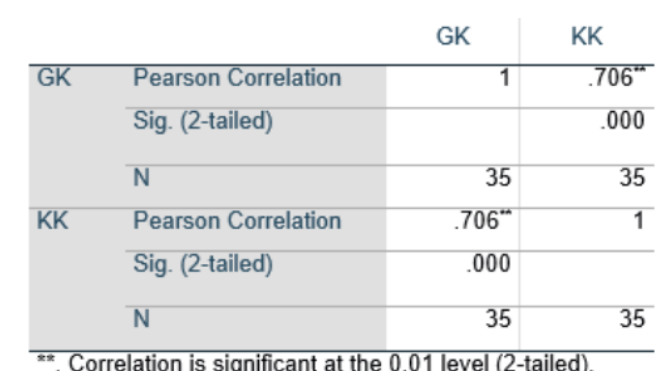

Berdasarkan tabel di atas, terlihat koefisien korelasi sebesar 706**. Artinya besar korelasi atau hubungan antara variabel gaya kepemimpinan terhadap kinerja karyawan sebesar 0,706 atau bisa dikatakan cukup karena mendekati angka 1. Tanda dua bintang (**) artinya korelasi signifikan hingga pada angka signifikan sebesar 0,001. Berdasarkan tabel diatas hubungan variabel gaya kepemimpinan terhadap kinerja karyawan signifikan karena angka signifikan sebesar 0,000 >0,01. Arah korelasi dapat dilihat dari angka koefisien hasilnya positif atau negatif. Sesuai dengan hasil analisis, koefisien korelasi jauh bernilai positif yaitu 0,706 maka korelasi kedua variabel bersifat searah.

\section{Hasil dan Pembahasan Uji Determinasi}

\section{Tabel 6. Hasil Uji Determinasi}

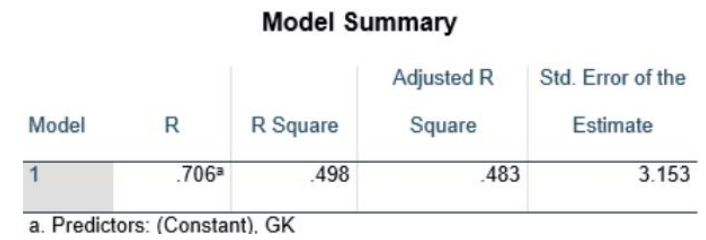

Dilihat dari tabel 4.12 hasil output spss diatas didapatkan nilai $\mathrm{R}$ (koefisien determinasi) 0,498 yang artinya pengaruh gaya kepemimpinan (independen) adalah sebesar 49,8\% ini menunjukkan bahwa nilai $\mathrm{R}$ hampir mencapai angka 1 dan variabel bebas dapat memberikan hampir semua informasi yang dibutuhkan untuk memprediksi variabel terikat (dependen).

\section{Hasil dan Pembahasan Uji Regresi}

\section{Tabel 7. Hasil Uji Regresi}

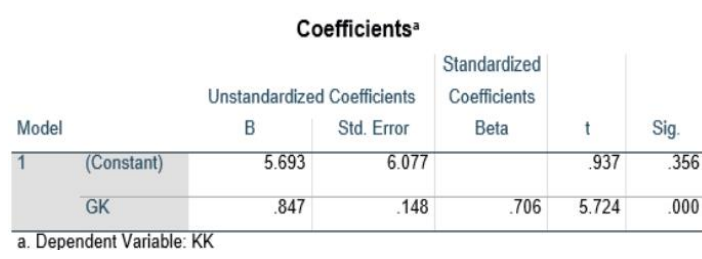

Dari data tabel 4.13 diatas perhitungan nilai regresi tersebut diperoleh nilai constant (a) sebesar 5,693 sedangkan nilai koefisien regresi sebesar 0,847 sehingga persamaan regresinya dapat ditulis sebagai berikut : 


$$
\begin{aligned}
& Y=a+b X \\
& Y=5,693+0,847 X
\end{aligned}
$$

Nilai konstanta sebesar 5,693 mengandung arti bahwa nilai konsisten variabel kinerja karyawan adalah 5,693. Dan nilai koefisien regresi $\mathrm{X}$ sebesar 0,847 menyatakan bahwa setiap penambahan $1 \%$ nilai motivasi kerja maka nilai kinerja karyawan bertambah sebesar 0,847. Dengan nilai signifikan adalah 0,000 ini menunjukkan bahwa nilai signifikan lebih dari 0,05 sehingga dapat disimpulkan bahwa variabel gaya kepemimpinan berpengaruh terhadap variabel kinerja karyawan.

\section{Hasil dan Pembahasan Uji Hipotesis}

\section{Tabel 8. Hasil Uji T (Parsial)}

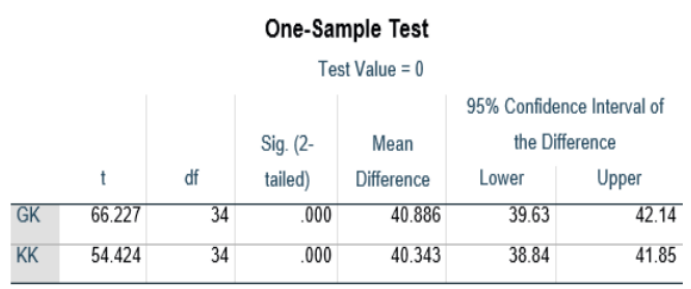

Sumber : Data Primer dikelola dengan SPSS versi 25

Dari tabel diatas dapat dilihat bahwa nilai signifikan adalah sebesar ,000. Sesuai dengan dasar pengambilan keputusan jika nilai signifikan lebih kecil dari pada nilai cronbach aplha (sig < 0,05) maka hipotesis diterima. Oleh karena itu dalam penelitian ini secara parsial adalah hipotesis diterima.

\section{KESIMPULAN}

Terdapat pengaruh yang signifikan gaya kepemimpinan terhadap kinerja karyawan, hal ini dibuktikan bahwa variabel (X) gaya kepemimpinan dan varibel (Y) kinerja karyawan memiliki nilai signikan lebi kecil dari 0,05 yaitu $(0,00<0,05)$.

Penjualan Perusahaan Depot Nanda mengalami penurunan pada bulan juni hingga September 2020 dibandingkan dengan bulan sebelumnya. Dimana penurunan penjualan tersebut sangat berpengaruh terhadap kesetabilan perusahaan. Ada beberapa hal yang berhubungan dengan kinerja karyawan Depot Nanda yang harus dapat perhatian yaitu masih di temukannya penetapan orang yang tidak pada tempatnya yakni tidak sesuai pada jabatan atau kemampuan kerjanya, kurangnya penghargaan terhadap karyawan yang berkinerja baik dan gaji yang kecil sehingga beberapa karyawan sering mengambil jam lembur untuk menambahi penghasilan mereka. Maka dapat di pastikan bahwa perilaku seorang pemimpin adalah pengaruh yang akan menimbulkan pemahaman tersendiri yang akan berpengaruh terhadap kondisi psikologi bawahannya, ada bawahan yang melihat, mengamati dan meniru. 
Variabel independen dikatakan secara parsial berpengaruh signifikan terhadap variabel dependen apabila signifikan (sig) $<\alpha$ yaitu 0.05 . Adapun tanda positif (+) atau negatif (-) dari Beta dan $\mathrm{t}$ menunjukkan arah variabel. Apabila negatif (-) maka variabel tersebut berpengaruh negatif artinya menurunkan tingkat volume penjualan dan apabila positif (+) maka variabel independen berpengaruh positif yang berarti meningkatkan volume penjualan. Terdapat hubungan yang signifikan pengaruh gaya kepemimpinan terhadap kinerja karyawan. Hal ini dapat dibuktikan dengan nilai signifikansi pada uji t secara parsial diperoleh nilai signisikan sebesar 0,00 lebih kecil dari 0,05 , sehingga dapat disimpulkan bahwa secara parsial hipotesis diterima dengan signifikan kuat.

\section{Saran}

Berdasarkan penelitian di atas, maka peneliti memberikan beberapa saran, sebagai berikut:

1. Untuk pemimpin Depot Nanda di Bekasi diharapkan lebih memperhatikan karyawannya, melakukan pendekatan kepada para karyawan agar karyawan di Depot Nanda bekerja lebih optimal dan lebih maksimal.
2. Untuk meningkatkan kembali kinerja karyawan tersebut, maka salah satu faktor yang perlu diperhatikan adalah gaya kepempinan yang diterapkan oleh pemimpin pada perusahaan yaitu bagaimana agar gaya kepemimpinan yang diterapkan para pemimpin dapat menunjang kinerja karyawan yang lebih baik. Informasi mengenai gaya kepemimpinan ini penting diketahui pihak perusahaan sendiri, karna gaya kepemimpinan merupakan salah satu komponen penting yang akan mempengaruhi kinerja karyawan dan secara lebih jauh akan mempengaruhi kinerja organisasi. Untuk karyawan depot nanda di bekasi di harapkan lebih semangat, lebih giat untuk bekerja dan saling bekerja sama untuk mencapai hasil maksimal yang di targetkan oleh perusahaan.

\section{REFERENSI}

Ali Wardana. (2019) pengaruh gaya kepemimpinan terhadap kinerja karyawan pada CV. Cipta kreasi di bekasi. Stie Tribuana Bekasi

Arini Yulianita. (2017) pengaruh gaya kepemimpinan dan motivasi terhadap kinerja karyawan $\mathrm{CV}$. CIPTA NUSA SIDOARJO. 
Universitas Muhammadiyah Sidoarjo

Dimas Ario Bimo. (2017) pengaruh gaya kepemimpinan terhadap kinerja karyawan di grand sakura hotel medan. Universitas Medan Area

Dr. Kasmir, S.E., M.M. Manajemen Sumber Daya Manusia (Teori dan Praktik). (Jakarta : PT. Raja Grafindo Persada, 2016)

Dr. Sopiah, M. Pd., M.M dan Dr. Etta Mamang Sangadji, M. Si. Manajemen Sumber Daya Manusia Strategik. (Bekasi : CV. Andi Offset, 2018)

Emilia Ika Andiyani. (2016) pengaruh gaya kepemimpinan terhadap kinerja kayawan RS. Panti Rapih Yogyakarta. Universitas Sanata Dharma Yogyakarta

Hj. Misriyani Niel. (2013) pengaruh gaya kepemimpinan terhadap kinerja pegawai pada dinas perhubungan kota makasar. Universitas Islam Negri Alauddin Makassar

Meta Dwi Lingga Sari. (2018) pengaruh gaya kepemimpinan terhadap kinerja karyawan pegawai dinas lingkungan hidup dan kebersihan kota Palembang. Universitas Sriwijaya Palembang
Nazir, Moh, 2019. Metodologi Penelitian. (Jakarta : Ghalia Indonesia)

Marpaung, N. N. (2021). Pengaruh Manajemen Tenaga Pendidik Terhadap Prestasi Belajar Peserta Didik di SD Harapan Indonesia Kota Bekasi. PARAMETER, 6(1), 12-23.

https://doi.org/10.37751/parameter. v6i1.158

Prof. Dr. H. Edy Sutrisno, M. Si. Manajemen Sumber Daya Manusia. (Jakarta : Kencana, 2010)

Rohma Nurlia. (2017) pengaruh gaya kepemimpinan terhadap kinerja karyawan pada PT. AL-IJARAH INDONESIA FINANCE LAMPUNG. Universitas Islam Negri Raden Intan Lampung

Rulli Setiadi. (2017) pengaruh gaya kepemimpinan terhadap kinerja karyawan Radix Haircut Bandung. Universitas Katolik Parayangan

Sugiyono, Metode Penelitian Kuantitatif dan Kualitatif, (Bandung: Alfabeta, 2013)

Sutrisno, E (2015). Manajemen Sumber Daya manusia. Jakarta : Kencana 